some human purpose? In the widest sense, therefore, all knowledge which is desired must be useful in some way and for some purposes, and, even on the most narrowly "utilitarian" interpretation, the useful is nothing else or more than what satisfies desire-except that an attempt is made to restrict it to the satis. faction of a very limited set of desires. An absolutely useless method or study would be one that could not be worked in any conceivable manner or for any conceivable purpose, i.e. it would be not merely useless, but false. The proper defence, therefore, of the so-called "useless" researches seems to me to consist in showing in the first place that the context of a science requires them, and in the second in pointing out that it has always, so far, proved possible to find a directly practical application for what is organically connected with a system of knowledge.

Corpus Christi College, Oxford.

F. C. S. Schiliter.

\section{The Field-mice and Wrens of St. Kilda and Shetland.}

Ix his notice of Messrs. A. H. Evans and T. E. Buckley's "Fauna of the Shetlands" (NATtre, May 24, 1900, pp. 75 and 76), your reviewer regrets that the authors are silent in regard to the special characters of the Shetland field-mouse, in view of my own recent recognition of a peculiar representation of this type in St. Kilda. It may be interesting to point out that in a recent paper on geographical and individual variation in Mites sylvaticus and its allies (P.Z.S., 1900, p. 387), I found myself unable to separate the Shetland field-mouse (suecimens of which I had fortunately been able to examine), at least at present, from that of Great Britain generally. I would not, however, therefore necessarily bind myself to follow your reviewer in his suggestion that the comparative distinctness of the local forms of wren and field-mouse may guide us in forming a decision as to the relative periods during which St. Kilda and the Shetlands have teen separated from the mainland. So many factors seem to be brought into play in the evolution of a local race or sub. species that it is, I fear, unsafe to rely ton much on such points, and $I$ have a strong suspicion that the influence of the environment has been too little taken into account by recent writers. At all events the field-mouse of Iceland would, it might be thought, show remarkable deviations from the mice of Western Europe, yet the little that we knuw of it only shows us how closely allied it is to Murs sylvaticus proper.

As regards the wrens of Iceland and of the various Scotch islands, attention may be (lirected to an interesting series of measurements of wings given by $\mathrm{Mr}$. K. M. Barrington in a fontnote to p. 64I of his book on "The Migration of Birds as Observed at the Irish Lighthouses and Lightships." These seem to show a gradual diminution in size from the large Tro. glodytes borealis of Iceland through the Shetland wren, which, although smaller than $T$. borealis, seems to be larger than $T$. hirtensis of St. Kilda ; the latter exceeds in size the wrens of Ireland. But no doubt intermediates occur, and a wing receired from the lighthouse on the Tuskar rock off the Wexford coast in October, I888, equals that of a specimen from St. Kilda, whence, perhaps, it may have been a migrant.

(i. F. H. BARRETT-HAMIITON.

Kilmanock, Arthurstown, Waterford, Ireland.

\section{Sexual Dimorphism.}

IF Prof. Meldola does not suppose that all spontaneous varia tions are limited in inheritance to one sex, he is logically bound to admit that the theory of sexual selection does not explain unisexual inheritance. There can be no possibility of verbal jugele in my arguments, brcause I define a secondary sexual characier as one that is affected by castration, one that does not develop normally after removal of the generative organs, a spontaneous variation as one that is not produced by the conditions of life.

But it is not my theory that "the stimulations which pro. duced a male character necessitate the restriction of that character to the male," and therefore I am not affected by the dilemma in which Prof. Meldola thinks I an placed. On p. 94 of $\mathrm{my}$ took will be found these words :-

"It is possible that unisexual characters originally developed by special stimulations related to reproduction, tend sooner or later to be inherited in common by all individuals of the species, that, considered in relation to periods of evolution, their sexual limitation is only temporary."

I fear that Prof. Mieldola has not yet sufficiently considered my theory.

Penzance, January II. J. T. CvNingham.

No. 1630 , voL. 63]
THE theory of sexual selection never pretended to explain unisexual inheritance. Its author started with a fact:- "Inasmuch as peculiarities often appear under domestication in one sex and become hereditarily attached to that sex, so no doubt it will be under nature" ("Origin of Species," 6th ed. p. 69) ${ }^{\mathrm{i}}$ Neither does the theory of natural selection pretend to explain ordinary, i.e. bisexual, inheritance. But Mr. Cunningham pretends that his theory does explain unisexual inheritance, and having -in spite of the statement contained in the concluding sentence of the above letter-given very full consideration to his views, I have come to the opposite conclusion. I repeat that his theory does not explain unisexual inheritance.

Mr. Cunningham has now given a further and more restricted "definition" of secondary sexual characters. In this he has not only gone far beyond Darwin, but he has virtually cancelled at least half of his own book. The whole of the evidence that characters developed in one sex are latent in the other was summarised by Iarwin in 1868 :- "We thus see that in many, probably in all cases, the secondary characters of each sex lie dormant or latent in the opposite sex, ready to be evolved under peculiar circumstances" ("Variation of Animals and Plants," Ist ed. vol. ii. p. 52). All the evidence with regard to secondary sexual characters which Darwin considered in arriving at the above conclusion was based on cases observed in mammals and birds, and, with his well-known caution, he only admits probability in extending it to all cases. But Mr. Cunningham now has converted Darwin's cautiously expressed probability into a "definition"! In doing this he has practically wiped out the whole body of material relating to classes other than mammals and birds which he has brought together in his own work. I confess that I have not of late years been able to follow very closely the progress of knowledge in this direction, but, so far as I know, there is no single observation, with the exception, perhaps, of Stylopised bees, which would bring the secondary sexual characters of fishes, reptiles, crustacea, insects, \&.c., within Mr. Cunningham's definition. Is there any known case among these lower groups where the "removal of the generative organs" (to use Mr. Cunningham's own expression) leads to the appearance of the characters of one sex in individuals of the other sex?

There is another inexplicable statement in the above letter: "It is not my theory that "the stimulations which produced a male character necessitate the restriction of that character to the male." I must again quote Mr. Cunningham's own remark of December 29, 1900. "My theory is that they (the variations) were so limited in development because they were due to stimu lations similarly limited" (NATURE, January 10, p. 252). If this does not mean that he is attempting to explain the sexual limitation of characters by "stimsulations" applied originally to the sex in which they are now developed, then it appears that he has abandoned his fundamental proposition, viz., that his theory explains unisexual inheritance. The restriction of this sexually limited inheritance by considering it temporary instead of permanent, as indicated in the passage quoted by $\mathrm{Mr}$. Cunningham at the conclusion of the above letter, does not affect the argument in any way. We still have to learn how and why the theory of "stimulations" explains unisexual inheritance, even if the latter be only temporary.

I venture to think that editorial hospitality has been suff. ciently taxed in connection with this subject. So far as I am concerned I must beg .Ir. Cunningham to consider the discussion as closed. The issue is befure the readers of these columns, and I do not think that any further advance is likely to be made by mere iteration and reiteration. I consider that indirectly the author of "Sexual Dimorphism" has done excellent service to the cause of Darwinian evolution by enabling us to realise how a well-conceived and well-worked-out application of Lamarckian principles completely breaks down on critical examination.

January 12.

R. MELDOLA.

\section{Very Cold Days.}

THE following account of days on which the minimum temperature was under $20^{\circ}$ (at (Greenwich) may be found instructive.

There have been 162 of these very cold days in the last sixty

1 "We may conclude that one cause, though not the sole cause, of characters being exclusively inherited by one sex, is their develupment at a late age "("1)escen: of .1an," \&c. 1st ed. vol. i. p. 2(5). "This is the utmost extent of Darwin's application of the evidence in discussing the sextral himi"pangenesis" (loc. cit. p. $23_{4}$ ). 